\title{
Influence of calcite on the microstructure and sintering properties of the porcelain ceramic tiles at low temperature
}

\author{
Qifu BAO, Weixia DONG $\dagger$, Jian-er ZHOU, Kun LIU and Tiangui ZHAO \\ Department of material Science and Engineering, Jingdezhen Ceramic Institute, Jingdezhen 333001, P. R. China
}

\begin{abstract}
Porcelain ceramic tiles are low-temperature prepared by introducing multiple fluxes. The multiple flux compositions are potash feldspar-sodium feldspar-lithium porcelain stone- calcite four flux system. Effects of calcite contents on the microstructure, sintering and mechanical properties of the samples are studied in a fast firing process. The sintering behaviors of the samples are evaluated by linear shrinkage, water absorption and bulk density. The fired samples are characterized by $\mathrm{X}$-ray diffraction, scanning electron microscopy equipped with an energy dispersive $\mathrm{X}$-ray spectroscopy and bending strength measurements. Well densification of the porcelain ceramic tiles is obtained at a low temperature $1130-1150{ }^{\circ} \mathrm{C}$. The sample prepared with $11 \%$ calcite exhibits higher shrinkage and bulk density, lower water absorption at a temperature of $1130^{\circ} \mathrm{C}$. Higher bending strength at a composition containing at $11 \%$ calcite is due to appropriate densification and high anorthite, quartz and mullite crystallinity. (C2017 The Ceramic Society of Japan. All rights reserved.
\end{abstract}

Key-words : Porcelain ceramic tile, Sintering properties, Low temperature, Calcite, Bending strength

[Received May 5, 2017; Accepted September 20, 2017]

\section{Introduction}

The production of ceramic tiles has been rapidly growing worldwide in recent years. Such an impressive growth implies an increasing raw materials and fuel. In china, the ceramic tile consumption can be estimated around 9600 million tons/year and thus, the gas consumption around 6 bn liters which exacerbated the greenhouse effect due to a large amount of $\mathrm{CO}_{2}$ emission. ${ }^{1), 2)}$ In recent years, technological revolutions like fast firing and the enhancement of product quality (e. g. porcelain tile) took place in the past decades in the world. ${ }^{3), 4)}$ As a consequence, reducing the firing temperature for porcelain tile is also an important method to save energy and reduce $\mathrm{CO}_{2}$ emission in ceramic industry. Some researchers reported that the substantial increase of one or two kinds of low temperature flux contents were introduced for the current high-temperature porcelain building ceramics. However, poor quality products with the soft collapse and deformation problems are often obtained due to the amount of liquid phase increases dramatically. ${ }^{5)-10)}$ Therefore, the firing temperature of porcelain tiles have been kept at high temperature of 1200$1240^{\circ} \mathrm{C}$. In previous report, ${ }^{11), 12)}$ our team reduced the sintering temperature by introducing " $\mathrm{K}_{2} \mathrm{O}-\mathrm{Na}_{2} \mathrm{O}-\mathrm{Li}_{2} \mathrm{O}$ " flux to obtain good quality products. To further reduce the firing temperature, it was investigated about $\mathrm{CaO}-\mathrm{Li}_{2} \mathrm{O}-\mathrm{K}_{2} \mathrm{O}-\mathrm{Na}_{2} \mathrm{O}$ system using grammite. However, the sintering temperature is not significantly reduced by using grammite. Compared with the use of grammite, calcite can obviously reduce the sintering temperature, because its reaction activity is far higher than that of grammite, which is due to calcite decomposition into calcium oxide and carbon dioxide. In addition, there are some reports that calcite is added to porcelain, it is possible to sinter at $1000^{\circ} \mathrm{C}$ or less. ${ }^{13), 14)}$ Although calcite is not helpful for environmental protect due to the release of $\mathrm{CO}_{2}$, a significant reduction of carbon dioxide emissions by decreasing the firing temperature using calcite is far more obvious than carbon dioxide released from calcite. And it is possible

Corresponding author: W. Dong; E-mail: weixia_dong@sina.com to improve the effect of rapid firing on the densification of porcelain tile. ${ }^{13), 14)}$ Therefore, in our paper, the present work aims to elucidate the influence of calcite on the microstructure and technological properties of the porcelain tiles at low temperature, including sintering behavior, bending strength and so on. Assuredly, low-temperature sintering results in the reduction in the fuel costs and $\mathrm{CO}_{2}$ emission of porcelain tile of the desired technological properties.

\section{Experimental processes}

All the raw materials were powders. The average particle sizes of the sodium feldspar, potash feldspar, lithium stone and calcite used are 5.7, 4.6, 14.5 and $5.8 \mu \mathrm{m}$, respectively. The chemical compositions of the starting raw materials were shown in Table 1. Porcelain tile compositions were prepared using a mixture of 13.6 $\mathrm{wt} \%$ kaolin, $5.4 \mathrm{wt} \%$ ball clay, $16 \mathrm{wt} \%$ sodium feldspar, $4 \mathrm{wt} \%$ potash feldspar, $11 \mathrm{wt} \%$ lithium stone, $22.8 \mathrm{wt} \%$ sandstone and $27.2 \mathrm{wt} \%$ potassic sand with the addition of calcite contents $(0,5$, $9,11,13,15$ and 17\%), respectively. The above-noted compositions were prepared by the following ceramic process. The raw materials were wet-ball milled thoroughly for $10 \mathrm{~h}$. The resultant slurry was oven-dried at $80^{\circ} \mathrm{C}$ with a moisture of $3-7 \%$ water and screened (screen size is $63 \mu \mathrm{m}$ ). $3 \mathrm{~g}$ of the batch was uniaxially pressed at $10 \mathrm{MPa}$ in a steel mode of discs $(25 \mathrm{~mm} \times 5 \mathrm{~mm})$ and rectangular $(70 \times 10 \times 10 \mathrm{~mm})$. The green bodies were dried in an oven at $90^{\circ} \mathrm{C}$ for $24 \mathrm{~h}$, and fired at the temperature range of $700-1190^{\circ} \mathrm{C}$ for soaking time of $0.5 \mathrm{~h}$ (the heating and cooling rate of $3{ }^{\circ} \mathrm{C} / \mathrm{min}$, respectively). Ten specimen bodies for each batch composition were averaged for the bulk density, water adsorption, linear shrinkage and bending strength.

The water absorption $(\%)$ and bulk density $\left(\mathrm{g} / \mathrm{cm}^{3}\right)$ were measured according to Archimedes principle. ${ }^{11), 15)}$ The crystalline phases were characterized by X-ray diffraction (XRD) in a German D8-Advance diffractometer in the range $2 \theta$ of $5-70^{\circ}$ at a scanning speed of $0.04^{\circ} / \mathrm{min}$, using $\mathrm{Cu} \mathrm{K}_{\alpha}$ radiation at $50 \mathrm{kV}$ and $30 \mathrm{~mA}$. The morphology observation were employed by a Japan Hitachi S-4800 field emission scanning electron microscopy 
Table 1. Chemical composition $(\%)$ of the raw materials

\begin{tabular}{crrrrrrrrrrr}
\hline Raw materials & $\mathrm{SiO}_{2}$ & $\mathrm{Al}_{2} \mathrm{O}_{3}$ & $\mathrm{Fe}_{2} \mathrm{O}_{3}$ & $\mathrm{CaO}$ & $\mathrm{MgO}$ & $\mathrm{K}_{2} \mathrm{O}$ & $\mathrm{Na}_{2} \mathrm{O}$ & $\mathrm{TiO}_{2}$ & $\mathrm{Li}_{2} \mathrm{O}$ & \multicolumn{1}{l}{$\mathrm{IL}$} & \multicolumn{1}{l}{ total } \\
\hline Sandstone & 74.04 & 16.67 & 0.59 & 0.41 & 0.71 & 3.48 & 0.66 & 0.10 & - & 3.14 & 99.80 \\
Potash feldspar & 71.46 & 16.24 & 0.15 & 0.15 & 0.07 & 7.07 & 3.30 & 0.02 & - & 1.19 & 99.65 \\
Potassic sand & 74.70 & 13.52 & 0.16 & 1.06 & 0.47 & 5.94 & 2.88 & 0.02 & - & 1.28 \\
Clay & 68.64 & 20.16 & 1.00 & 0.09 & 0.20 & 1.89 & 0.47 & 0.40 & - & 6.69 & 99.03 \\
Ball clay & 51.14 & 33.87 & 0.47 & 0.10 & 0.15 & 0.70 & 0.42 & 0.07 & - & 12.56 & 99.48 \\
Sodium feldspar & 70.32 & 17.79 & 0.11 & 0.53 & 0.15 & 2.75 & 7.30 & 0.02 & - & 0.75 \\
Lithium stone & 67.46 & 19.68 & 0.03 & 0.39 & 0.12 & 4.80 & 3.66 & 0.01 & 1.76 & 2.47 \\
Calcite & 0.38 & 0.10 & 0.09 & 55.87 & 0.27 & - & - & 0.01 & - & 43.28 & 96.38 \\
\hline
\end{tabular}
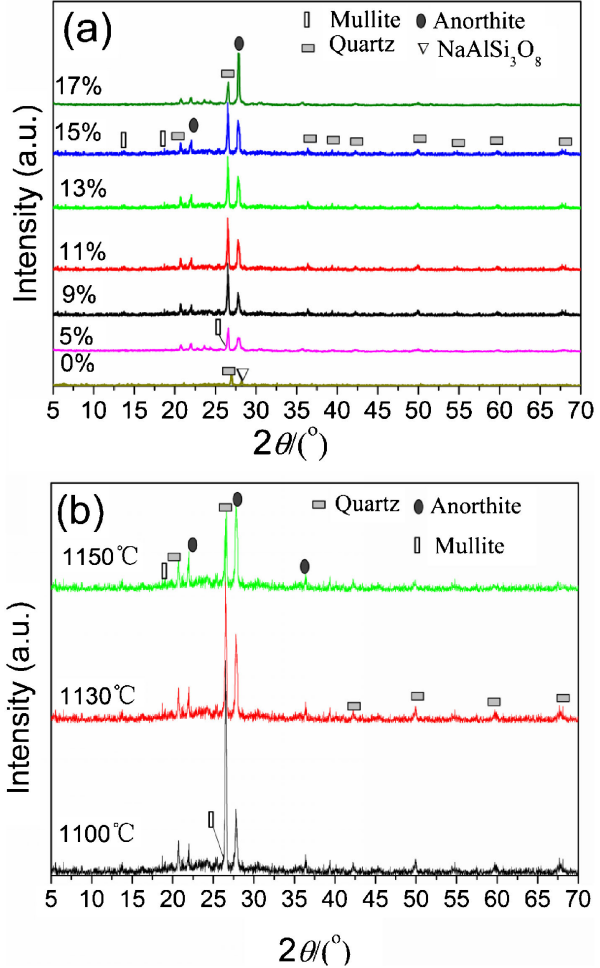

Fig. 1. XRD patterns of the samples (a) with various calcite contents at the temperature of $1130^{\circ} \mathrm{C}$, (b) with $11 \%$ calcite at various temperature.

(FESEM) equipped with an energy dispersive spectroscopy (EDS) system operating at an accelerating voltage of 5.0 or $15 \mathrm{kV}$ (15 kV for EDS). A DWD 3020 electronic universal (Shanghai Testing Machine Co., LTD, China) was employed for the bending strength of the samples. The differential thermal analysis/ thermogravimetry (DTA-TG) was carried out on a NETZSHSTA 449C (Netzsch, German) in the temperature range of $20-1200^{\circ} \mathrm{C}$ at a heating rate of $5{ }^{\circ} \mathrm{C} / \mathrm{min}$ in flowing air. To analysis of phase assemblages and morphology, the fresh fracture surfaces of the samples were etched for $30 \mathrm{~min}$ in 5\% HF solution.

\section{Results and discussion}

Figure 1(a) shows XRD patterns of the samples prepared at various calcite contents. When calcite is $0 \%$, the sample is composed of $\mathrm{NaAlSi}_{3} \mathrm{O}_{8}$ phase and quartz $\left(\mathrm{SiO}_{2}\right.$, JCPDS card no. 04-007-0522). After calcite is added, the main crystalline phases e. g. quartz ( $\mathrm{SiO}_{2}$, JCPDS card no. 04-007-0522), anorthite $\left(\mathrm{CaAl}_{2} \mathrm{Si}_{2} \mathrm{O}_{8}, \mathrm{JCPDS}\right.$ card no. 20-0528) and mullite $\left(\left(\mathrm{Al}_{6} \mathrm{Si}_{2} \mathrm{O}_{13}\right.\right.$, JCPDS card no. 15-0776) are obtained. With the calcite content increase, anorthite phase increases, however, mullite and quartz phase decrease. Figure 1(b) shows the XRD patterns of the samples prepared with $11 \%$ calcite at different temperature. It can

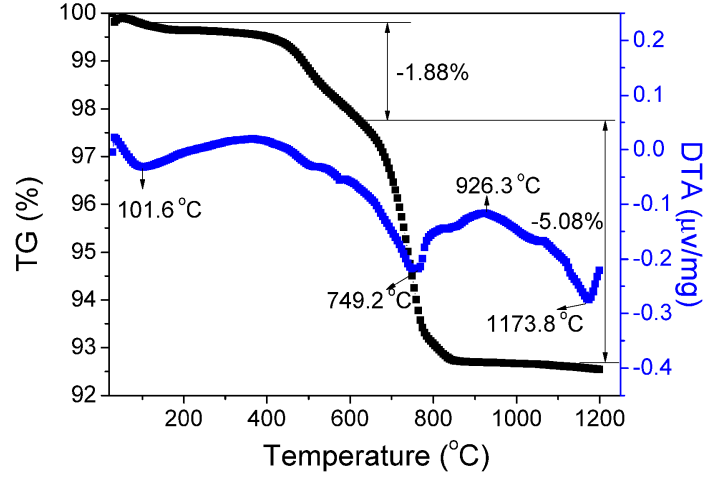

Fig. 2. DTA-TG curve of the green sample prepared at $11 \%$ calcite content.

be seen that all the samples are composed of quartz, anorthite and a little of mullite phase. With the increase of firing temperature, the intensity of quartz phase decreases and that of anorthite phase increases. Mullite phase has no obvious changes. It can be due to a small amount of mullite and its extremely small size which is not detected. It also indicate that the formation of a primary mullite can not sufficiently develop at lower temperatures. ${ }^{15)}$ The large amount of calcite as a flux $(>11 \%)$ is available for the further increase of the anorthite crystalline phases, whereas decreases mullite phase and silica phase. According to V. F. Pavlov, et al., ${ }^{16)}$ the addition of alkali oxides can delays the crystallization of cristobalite and lowers the formation temperature of mullite. In our experiment, the chemical composition of raw material shows a relatively large amount of alkali and alkalineearth oxides in addition with $\mathrm{SiO}_{2}$ and $\mathrm{Al}_{2} \mathrm{O}_{3}$ (Table 1). Ca cations could change the coordination of $\mathrm{Al}$ from six to four resulting in $\mathrm{Si}-\mathrm{O}-\mathrm{Al}$ bonds formation in the melt, and thus not help constructing the various modified lattices of silica and slow down the conversion of silica to cristobalite. ${ }^{17), 18)}$ The formation of anorthite is attributed to the calcium oxides reaction with metakaolinite following in Eqs. (1)-(3) from the related phase diagram of simple composition " $\mathrm{CaO}-\mathrm{Al}_{2} \mathrm{O}_{3}-\mathrm{SiO}_{2}$ ". ${ }^{19)}$ With the increase of calcite content $(>11 \%)$, the reaction between the mullite and the excess of calcium oxide in the presence of silica forms anorthite phase according to the following reaction Eq. (3). Therefore, the formation of mullite and silica crystals reduces (Fig. 1).

$$
\begin{aligned}
& \mathrm{Al}_{2} \mathrm{O}_{3} \cdot 2 \mathrm{SiO}_{2} \cdot 2 \mathrm{H}_{2} \mathrm{O} \rightarrow \mathrm{Al}_{2} \mathrm{O}_{3} \cdot 2 \mathrm{SiO}_{2}+2 \mathrm{H}_{2} \mathrm{O} \\
& \mathrm{Al}_{2} \mathrm{O}_{3} \cdot 2 \mathrm{SiO}_{2} \rightarrow(1 / 3)\left(3 \mathrm{Al}_{2} \mathrm{O}_{3} \cdot 2 \mathrm{SiO}_{2}\right)+(4 / 3) \mathrm{SiO}_{2} \\
& 3 \mathrm{Al}_{2} \mathrm{O}_{3} \cdot 2 \mathrm{SiO}_{2}+4 \mathrm{SiO}_{2}+3 \mathrm{CaO} \\
& \quad \rightarrow 3\left(\mathrm{CaO} \cdot \mathrm{Al}_{2} \mathrm{O}_{3} \cdot 2 \mathrm{SiO}_{2}\right)
\end{aligned}
$$

Figure 2 shows DTA-TG curve of the green sample prepared at $11 \%$ calcite contents. A weak exothermic DTA peak at $101.6^{\circ} \mathrm{C}$ and an initial weight loss of $1.88 \%$ is observed in the TG curve 

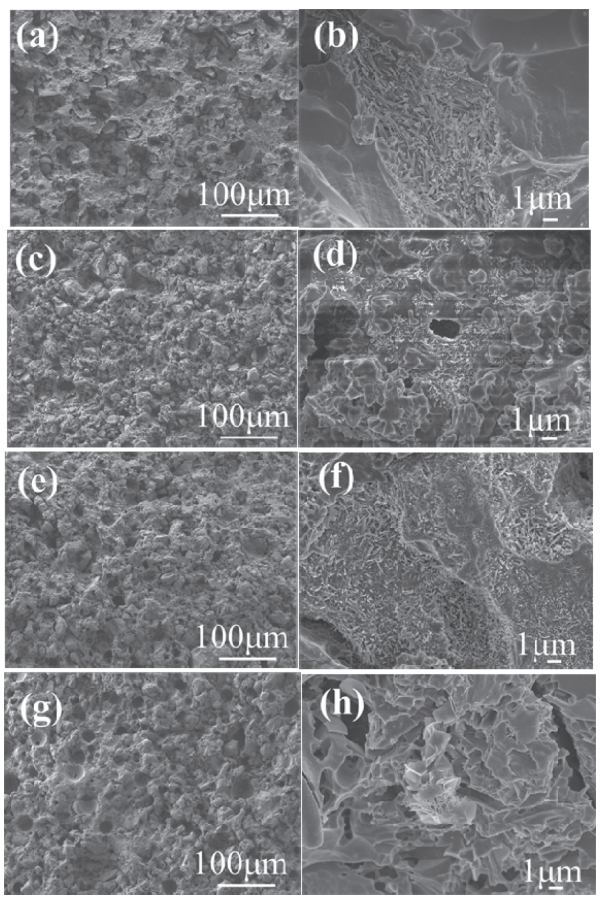

Fig. 3. Typical SEM fracture images of the samples prepared at various calcite contents: (a, b) $0 \%,(\mathrm{c}, \mathrm{d}) 9 \%,(\mathrm{e}, \mathrm{f}) 11 \%,(\mathrm{~g}, \mathrm{~h}) 17 \%$ at the temperature of $1130^{\circ} \mathrm{C}$ (etched by immersion in $3 \% \mathrm{HF}$ solution for $30 \mathrm{~min}$ ).

which is attributable to the adhesion water and dehydration of crystal water of clay minerals. A strong endothermic peak centered at $749.2^{\circ} \mathrm{C}$ is due to calcite decomposition. Corresponding to this peak, the TG curve indicates a maximum weight loss of $5.08 \%$. Meanwhile, there is a weak exothermic peaks at $926.3^{\circ} \mathrm{C}$ without the obvious weight loss, which is attributed to $\mathrm{Si}-\mathrm{Al}$ spinel-type structure formation from transformed by metakaolin. ${ }^{20)}$ There is an obvious endothermic peak at $1173.8^{\circ} \mathrm{C}$ without loss weight which indicates that the formation of anorthite according to Eq. (3). ${ }^{21)}$

Figure 3 shows typical SEM fracture images of calcite free and various calcite contents containing samples at the temperature of $1130^{\circ} \mathrm{C}$ etched by immersion in $3 \% \mathrm{HF}$ solution for $30 \mathrm{~min}$. Calcite free sample has many small crystals. However, calcite containing samples generally revealed a fine grained matrix of crystals. With the increase of calcite content, the pore size increases [Figs. 3(c), 3(e) and 3(g)]. The enlarged microstructure of the sample prepared with $9 \%$, the sample is composed of some crystals. Increasing calcite to $11 \%$, the sample is composed of some crystals, however, undissolved quartz (See Fig. 4) reduces, which is consistent with the results in Fig. 1. Further increasing calcite content to $17 \%$, the sample is composed of interlocking lamellar plates cystals and long and narrow pores.

Figure 4 shows the enlarged SEM cross-section images of the samples with the addition of $11 \%$ calcite prepared at $1130^{\circ} \mathrm{C}$. It can be seen that the samples are composed of glassy phase, undissolved quartz [Fig. 4(a)], short rod-like crystals of 500$1000 \mathrm{~nm}$ in length and $100 \mathrm{~nm}$ in diameter [Fig. 4(b) in the square of Fig. 4(a)], and interlocking lamellar plates [Fig. 4(c) in the circle of Fig. 4(a)]. To further analysize the chemical composition of the lamellar plates and short rod-like crystals, EDS analysis is employed and the chemical compositions are listed in Table 2. It can be seen that the lamellar plates cystals [Fig. 4(c) in the circle of Fig. 4(a)] are composed of $\mathrm{Ca}, \mathrm{Al}, \mathrm{Si}$ and $\mathrm{O}$ elements, and the molar ratio of $\mathrm{Ca}: \mathrm{Al}: \mathrm{Si}$ is $1: 2: 2$, which is

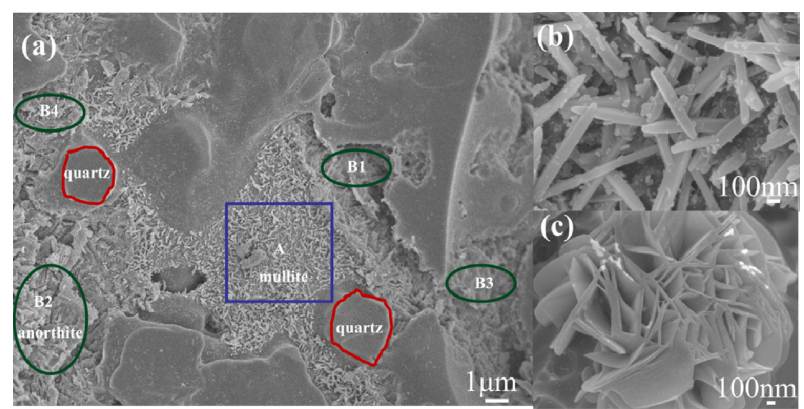

Fig. 4. SEM cross-section enlarged images of the samples with the addition of $11 \%$ calcite prepared at $1130^{\circ} \mathrm{C}$ : (a) the overall enlarged image, (b) the enlarged image of the square A in Figs. 4(a), (c) the enlarged image of circle B in Fig. 4(a).

Table 2. EDS analysis (weight and atomic percent of the elements, respectively) of the sample with the average for 8 points in Fig. 4(a)

\begin{tabular}{crrrrr}
\hline & \multicolumn{2}{c}{ Square A } & & \multicolumn{2}{c}{ Circle B } \\
\cline { 2 - 3 } \cline { 5 - 6 } Element & Weight & Atomic & & Weight & Atomic \\
& percent & percent & & percent & percent \\
\hline Al K & 33.15 & 27.84 & & 18.68 & 14.57 \\
Si K & 13.39 & 9.03 & & 18.63 & 14.54 \\
Ca K & 0.09 & 0.50 & & 4.71 & 6.32 \\
Na K & 0.50 & 0.44 & & - & - \\
K K & 0.40 & 0.38 & & - & - \\
O K & 53.28 & 61.81 & & 57.98 & 64.57 \\
Total & 100.00 & 100.00 & & 100.00 & 100.00 \\
\hline
\end{tabular}

consistent with the stoichiometric of the anorthite. The short rodlike crystals [Fig. 4(b) in the square of Fig. 4(a)] are composed of $\mathrm{Al}$, Si and $\mathrm{O}$ elements, the molar ratio of $\mathrm{Al}: \mathrm{Si}$ is $3: 1$, which is consistent with the stoichiometric of the mullite.

Linear shrinkage, water absorption and bulk density are important parameters for sintering properties of the samples. Figure 5 shows the linear shrinkage, water absorption and bulk density of the samples with addition of various calcite contents. It can be seen that water adsorption and linear shrinkage show average values of about 0.44 and $7.68 \%$ for the samples sintered at $1130^{\circ} \mathrm{C}$, respectively. The lowest water absorption $(0.09 \%)$, largest linear shrinkage $(6.18 \%)$ of the sample appears when calcite content is $11 \%$. Densification of the samples reaches the maximum values of $2.34 \mathrm{~g} / \mathrm{cm}^{3}$ at calcite of $11 \%$. The lower density values observed for the samples are directly related to the higher porosity and low particle packing, which are modified by the formation of the glassy phase, anorthite and mullite phase with the increase of calcite contents (Figs. 1 and 3). Figure 6 shows the bending strength of the samples with addition of various calcite contents. The bending strength of the samples initially increases and then decreases. At calcite content of $11 \%$, the sample reaches the maximum value of $56.15 \mathrm{MPa}$. As above all the experimental results, calcite does not always produce the better bending strength. When calcite content is low $(<11 \%)$, calcium ions could exist as a silicate glass phase, which promotes silica dissolution and the formation of the mullite and anorthite phase [Fig. 1(a)]. Some residual quartz and lamellar plate-like anorthite aggregate around the silica phase, and short rod-like mullite phase appear in the glassy phase (Figs. 2 and 4). It is due to dense structure of aggregated short rod-like mullite phase, lamellar plate-like anorthite and glassy phase, and thus improve the bending strength of the samples. Further increasing calcite contents to more than $11 \%$, calcite decomposes into more $\mathrm{CaO}$ 

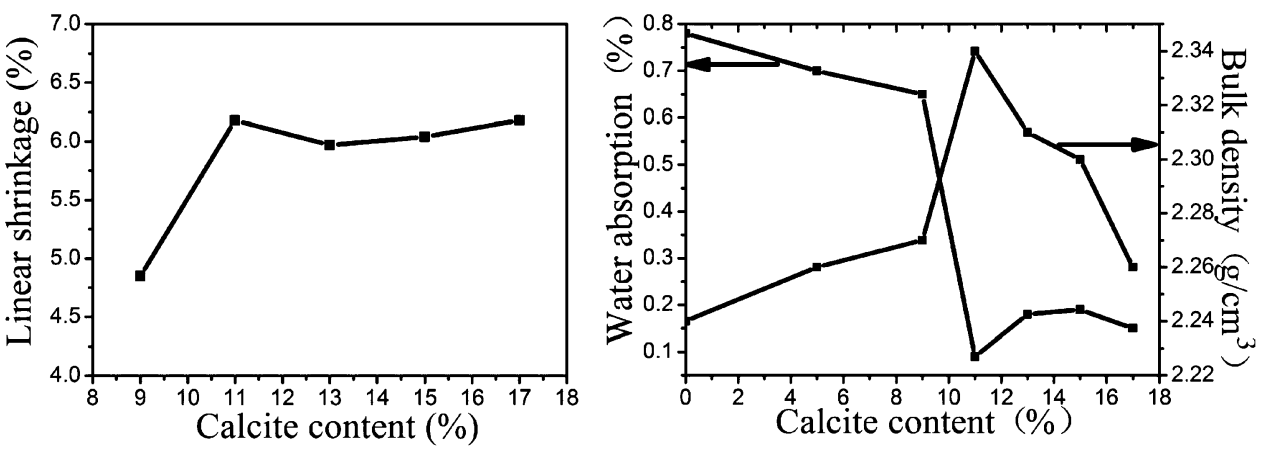

Fig. 5. The linear shrinkage, water absorption and bulk density of the samples with addition of various calcite contents at the temperature of $1130^{\circ} \mathrm{C}$.

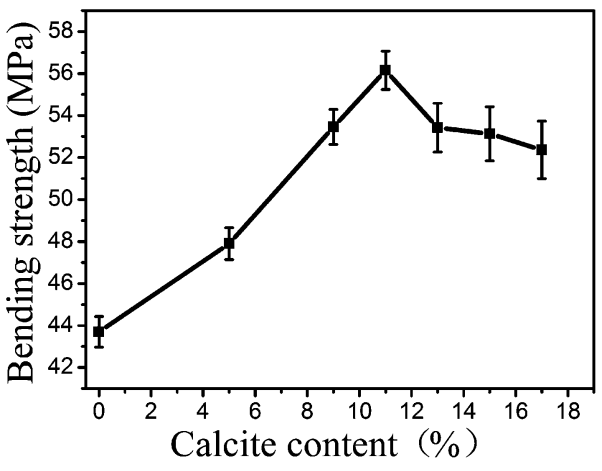

Fig. 6. The bending strength of the samples with various calcite contents at $1130^{\circ} \mathrm{C}$.

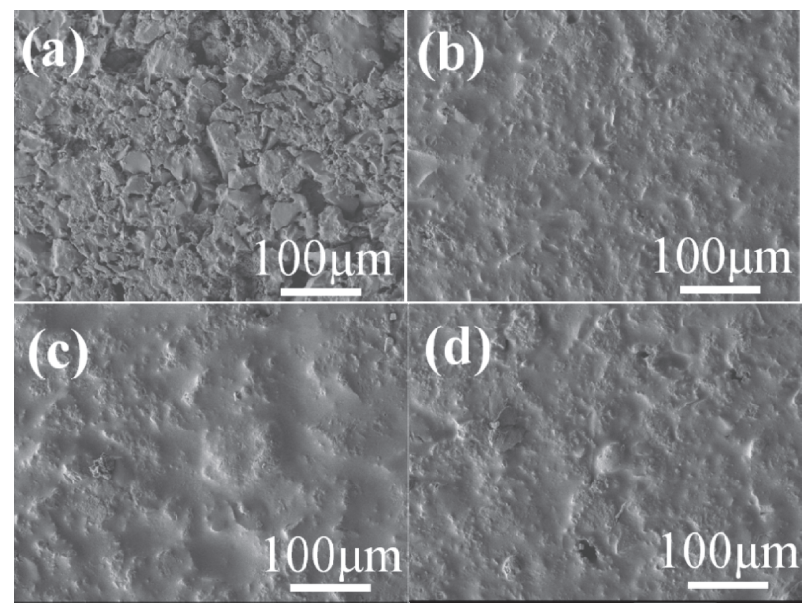

Fig. 7. SEM surface images of the samples with the addition of $11 \%$ calcite prepared at different temperatures: (a) $1100^{\circ} \mathrm{C}$, (b) $1130^{\circ} \mathrm{C}$, (c) $1150^{\circ} \mathrm{C}$, (d) $1190^{\circ} \mathrm{C}$.

and $\mathrm{CO}_{2}$ as a pore sources which provides the favorable space for the lamellar plate-like structure growth of anorthite. ${ }^{22)}$ The lamellar plate-like structure of anorthite can't merge very well together resulting in the pores or porosity [Figs. $3(\mathrm{~g})-3(\mathrm{~h})]$. Although calcite $(>11 \%)$ increases anorthite phase, the pore increases markedly coupled with a high amount of quartz, which introduce large pores and micocracks to lower the bending strength. ${ }^{23), 24)}$

Figure 7 shows SEM surface images of the samples with the addition of $11 \%$ calcite prepared at different temperature. When the temperature is lower than $1100^{\circ} \mathrm{C}$, the sample is not dense due to a small amount of glass phase. Further increasing the firing temperature can result in the increase of liquid phase amount and
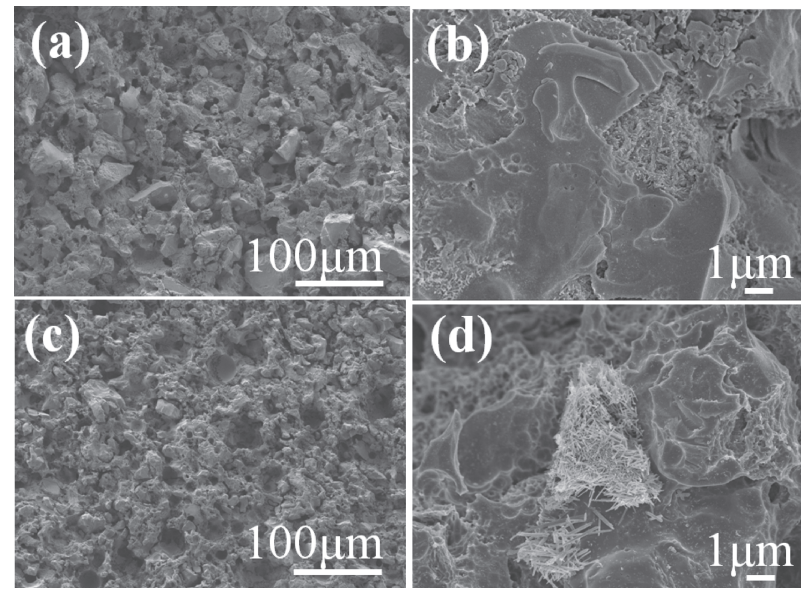

Fig. 8. SEM cross-section images of the samples with the addition of $11 \%$ calcite prepared at different temperature: (a, b) $1100^{\circ} \mathrm{C},(\mathrm{c}, \mathrm{d})$ $1190^{\circ} \mathrm{C}$ (etched by immersion in $3 \% \mathrm{HF}$ solution for $30 \mathrm{~min}$ ).

a decrease in liquid phase viscosity. The liquid phase tends to draw the particles and thus open porosity decreases, and closed porosity increases. ${ }^{25)}$ Therefore, when the firing temperature is $1130^{\circ} \mathrm{C}$, the samples become denser during firing. However, further increasing the temperature to over $1150^{\circ} \mathrm{C}$, the so-called body bloating tends to expand the pores due to the pressure of the gas inside the closed pores and thus the open pores increase, ${ }^{26}$ ) which is accordance with the result of the properties e. g. water absorption and firing linear shrinkage in Fig. 9.

Figure 8 shows SEM cross-section images of the samples with the addition of $11 \%$ calcite prepared at different temperature. Some crystals, and undissolved quartz are obtained in the samples. It can be obviously seen that with the increase of the temperature, the pore size becomes large, especially at the temperature of $1190^{\circ} \mathrm{C}$, which further indicates the sample is over sintering due to the increase of the liquid phase content.

Figure 9 shows the water absorption, bulk density, linear shrinkage and the bending strength of the samples at $11 \%$ calcite as a function of the temperature. The bending strength of the samples initially increases and then decreases. As for the samples with $11 \%$ calcite content, the bulk densities and linear shrinkage of the samples increased with increasing sintering temperature and then decreased. However, the bulk density and linear shrinkage of samples sintered at $1150^{\circ} \mathrm{C}$ was slightly less than those of samples sintered at $1130^{\circ} \mathrm{C}$, which was inconsistent with the sintering densification. It maybe be attributed to crystals growth under the condition of high porosity, which would need be further investigated. The bending strength of the samples dramatically 

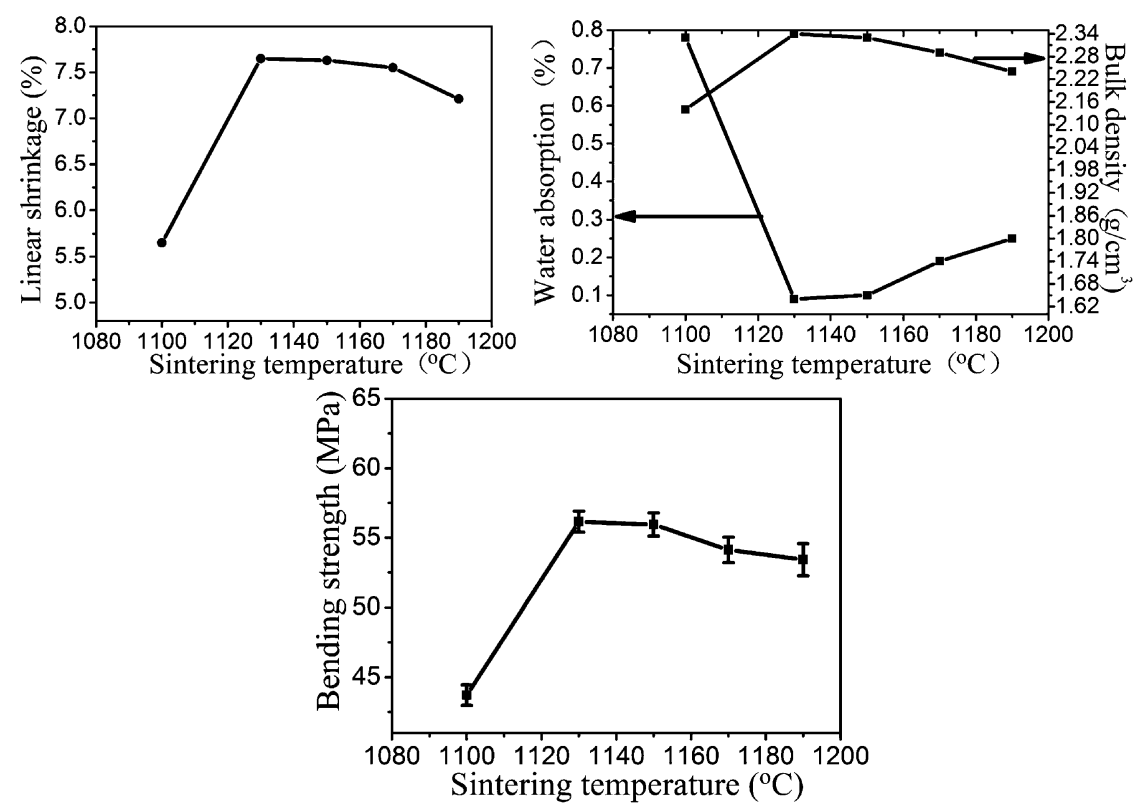

Fig. 9. Linear shrinkage, water absorption, bulking density and bending strength of the samples at $11 \%$ calcite as a function of the temperature.

Table 3. EDS analysis (weight percent of the oxides) of the samples with $11 \%$ calcite content at different temperature

\begin{tabular}{cccccccc}
\hline $\begin{array}{c}\text { Temperature } \\
\left({ }^{\circ} \mathrm{C}\right)\end{array}$ & $\mathrm{Na}_{2} \mathrm{O}$ & $\mathrm{K}_{2} \mathrm{O}$ & $\mathrm{Al}_{2} \mathrm{O}_{3}$ & $\mathrm{SiO}_{2}$ & $\mathrm{CaO}$ & $\mathrm{MgO}$ & Total \\
\hline 800 & 0.17 & 1.83 & 22.56 & 72.88 & 2.44 & 0.12 & 100.00 \\
900 & 0.39 & 1.95 & 21.77 & 73.49 & 2.28 & 0.12 & 100.00 \\
950 & 1.48 & 2.84 & 22.56 & 70.67 & 2.26 & 0.19 & 100.00 \\
1000 & 2.33 & 2.81 & 20.49 & 71.34 & 2.79 & 0.24 & 100.00 \\
1050 & 2.59 & 2.97 & 19.31 & 71.16 & 3.69 & 0.28 & 100.00 \\
1100 & 3.09 & 3.96 & 18.77 & 69.91 & 4.15 & 0.12 & 100.00 \\
1130 & 3.92 & 4.32 & 19.23 & 67.11 & 4.25 & 0.41 & 100.00 \\
1150 & 3.75 & 5.36 & 18.22 & 66.11 & 4.51 & 0.35 & 100.00 \\
1170 & 2.75 & 6.16 & 18.17 & 68.67 & 6.21 & 0.21 & 100.00 \\
1190 & 2.74 & 4.16 & 19.44 & 69.02 & 6.25 & 0.39 & 100.00 \\
1200 & 2.76 & 3.85 & 19.39 & 68.13 & 6.44 & 0.43 & 100.00 \\
\hline
\end{tabular}

rise and then decreased with an increase in temperature. The bending strength of the samples sintering at $1130-1150^{\circ} \mathrm{C}$ reach the maximum of 56.15-55.95 MPa. Probably, the lower firing temperature is responsible for the undense structure resulting in the low bending strength. With the temperature increase, water absorption decreased and thus the bending strength with increasing temperature due to the sintering densification. The higher strength of the samples can also be explained by the crystalline phases formed besides the densification and vitrification occurring during sintering. Further increasing temperature, although the interconnection of anorthite grains became stronger and quartz phase decreased, however, the liquid content increases rapidly and resulted in the sample over sintering (Fig. 9), thus the bending strength of the sample decreased. To further explain the low temperature mechanism of calcite as a flux, EDS analysis of the samples with $11 \%$ calcite content at different temperature are shown. Each sample takes 5 points analysis of glass phase composition, and calculates the average value as shown in Table 3. From Table 3, it can be seen that the glass phase could be formed at $800^{\circ} \mathrm{C}$ due to a little amount of $\mathrm{Na}_{2} \mathrm{O}, \mathrm{K}_{2} \mathrm{O}, \mathrm{CaO}$ and $\mathrm{MgO}$ contents in the glass phase, which is accordance with the eutectic point of " $\mathrm{K}_{2} \mathrm{O}-\mathrm{Na}_{2} \mathrm{O}-\mathrm{CaO}-\mathrm{MgO}$ " the phase diagram. With the increase of the temperature to $1130^{\circ} \mathrm{C}, \mathrm{Na}_{2} \mathrm{O}, \mathrm{K}_{2} \mathrm{O}, \mathrm{CaO}$ and $\mathrm{MgO}$ contents increase gradually, which indicate the increase of the glass phase with the temperature. However, further increase to the temperature of $1150^{\circ} \mathrm{C}$, the change of $\mathrm{Na}_{2} \mathrm{O}, \mathrm{K}_{2} \mathrm{O}, \mathrm{CaO}$ and $\mathrm{MgO}$ contents increase abruptly, which indicates a lot of liquid phase appears. When the temperature continues to increase, their contents keep almost unchanged due to over sintering. ${ }^{24)}$

\section{Conclusions}

In conclusion, porcelain ceramic tile with desirable physical and mechanical properties were prepared at low temperature of $1130-1150^{\circ} \mathrm{C}$. Doping with calcite enhanced the sinterability of the sample at low temperature. Calcite introduction can reduce the sintering temperature and increase the bending strength of the sample. The phases formed in the fired body are composed of quartz, anorthite, a small amount of mullite phase and glassy phase. The sample with $11 \%$ calcite content exhibited higher bulk density, bending strength and lower water absorption compared to those of the samples with various calcite contents due to appropriate densification and the formation of anorthite and mullite in the fired bodies. The liquid phases increase with increasing firing temperature and the calcite addition amount. Suitable liquid phase amount and low porosity reveal the full sintering of porcelain tiles.

Acknowledgement The present work was supported by the National Natural Science Foundation (Grant No. 51562013).

\section{References}

1) S. Liu, R. Tao and C. M. Tam, Habitat Int., 37, 155-162 (2013).

2) S. Liu, X. Meng and C. Tam, Energ. Buildings, 105, 139-153 (2015).

3) A. Boix, M. Gargallo, M. M. Jordan, R. Segura and T. Sanfeliu, Técn. Cerám., 224, 404-413 (1994).

4) M. Dondi, M. Raimondo and C. Zanelli, Appl. Clay Sci., 96, 91-109 (2014).

5) A. Salema, S. H. Jazayeri and E. Rastellic, Thermochim. Acta, 
503-504, 1-7 (2010).

6) H. J. Alves, M. R. Freitas and F. G. Melchiades, J. Eur. Ceram. Soc., 31, 665-671 (2011).

7) T. T. Bakop, R. T. Tene and U. C. Melo, J. Therm. Anal Calorim., 114, 113-123 (2013).

8) A. Salem and S. Aghahosseini, Thermochim. Acta, 545, 57-66 (2012).

9) E. Suvacia and N. Tamsua, J. Eur. Ceram. Soc., 30, 3071-3077 (2010).

10) S. Salem and A. Salem, Thermochim. Acta, 575, 322-330 (2014).

11) W. Dong, J. Zhou, X. Gu, Q. Bao, K. Liu and T. Zhao, Key Eng. Mat., 655, 253-257 (2015)

12) J. Zhou, K. Liu, W. Dong, Q. Bao, T. Zhao and Y. Wang, Key Eng. Mat., 655, 258-262 (2015).

13) Y. Kobayashi and E. Kato, J. Ceram. Soc. Jpn., 108, 271-276 (2010).

14) Y. Kobayashi, K. Sumi and E. Kato, J. Ceram. Soc. Jpn., 105, 670-674 (1997).

15) T. Zhao, W. Dong, Y. Shi, Q. Bao, J. Zhou and X. Liu, J. Ceram., 36, 54-57 (2015).

16) V. F. Pavlov and V. S. Mitrokhin, Trudy Instituta
NIlstroikeramika, 32, 53-75 (1979).

17) I. A. Aksay, D. M. Dabbs and M. Sarikaya, J. Am. Ceram Soc., 74, 2343-2358 (1991).

18) J. F. Li, H. Lin, J. B. Li and J. Wu, J. Eur. Ceram. Soc., 29, 2929-2936 (2009).

19) E. M. Levin, C. R. Robbins and H. F. Mcmurdie, Fig. 630. In Phase Diagrams for Ceramists, ed. M. K. Reser. American Ceramic Society, Columbus, OH (1964).

20) M. Hojamberdiev, A. Eminov and Y. Xu, Ceram. Int., 37, 871876 (2011).

21) P. Ptácek, T. Opravi, F. Soukal, J. Havlica and R. Hole, Solid State Sci., 26, 53-58 (2013).

22) X. Cheng, S. Ke, Q. Wang, H. Wang, A. Shui and P. Liu, Ceram. Int., 38, 3227-3235 (2012).

23) Z. Miao, N. Li and W. Yan, Ceram. Int., 40, 15795-15799 (2014).

24) M Dondi, G Ercolani, G Guarini, C Melandri, M Raimondo and Almendra, J. Eur. Ceram Soc., 25, 357-365 (2005).

25) M. J. Orts, A. Escardino, J. L. Amorós and F. Negre, Appl. Clay Sci., 8, 193-205 (1993).

26) J. Qin, C. Cuin, X. Cui, Ah. Hussain, C. Yang and S. Yang, Ceram. Int., 41, 5648-5655 (2015). 